Medieval Islamic medicine 


\section{The New Edinburgh Islamic Surveys \\ Series Editor: Carole Hillenbrand}

TITLES AVAILABLE OR FORTHCOMING

The New Islamic Dynasties Clifford Edmund Bosworth

Media Arabic Julia Ashtiany Bray

An Introduction to the Hadith John Burton

A History of Islamic Law Noel Coulson

Medieval Islamic Political Thought Patricia Crone

A Short History of the Ismailis Farhad Daftary

Islam: An Historical Introduction (2nd Edition) Gerhard Endress

A History of Christian-Muslim Relations Hugh Goddard

Shi ism (2nd Edition) Heinz Halm

Islamic Science and Engineering Donald Hill

Islamic Law: From Historical Foundations to Contemporary Practice Mawil Izzi Dien

Sufism: An Historical Introduction Ahmet T. Karamustafa

Islamic Aesthetics Oliver Leaman

Persian Historiography Julie Scott Meisami

Pilgrims and Pilgrimage Josef Meri

The Muslims of Medieval Italy Alex Metcalfe

The Archaeology of the Islamic World Marcus Milwright

Twelver Shi ism: Unity and Diversity in the Life of Islam Andrew Newman

Muslims in Western Europe (3rd Edition) Jørgen Nielsen

Medieval Islamic Medicine Peter E. Pormann and Emilie Savage-Smith

Islamic Names Annemarie Schimmel

Oral Tradition and Literacy in Classical Islam Gregor Schoeler

Modern Arabic Literature Paul Starkey

Islamic Medicine Manfred Ullman

Islam and Economics Ibrahim Warde

A History of Islamic Spain W. Montgomery Watt and Pierre Cachia

Introduction to the Qur'an W. Montgomery Watt

Islamic Creeds W. Montgomery Watt

Islamic Philosophy and Theology W. Montgomery Watt

Islamic Political Thought W. Montgomery Watt

The Influence of Islam on Medieval Europe W. Montgomery Watt

Understanding the Qur'an Alford Welch 


\title{
Medieval Islamic medicine
}

\author{
PETER E. PORMANN AND \\ EMILIE SAVAGE-SMITH
}

EDINBURGH UNIVERSITY PRESS 
(c) Peter E. Pormann and Emilie Savage-Smith, 2007

Transferred to digital print 2013

Edinburgh University Press Ltd 22 George Square, Edinburgh

Typeset in Goudy by Koinonia, Manchester, and printed and bound by CPI Group (UK) Ltd Croydon, CR0 4YY

A CIP Record for this book is available from the British Library

ISBN 978 ○ 74862066 I (hardback) ISBN 978 ○ 748620678 (paperback)

The right of Peter E. Pormann and Emilie Savage-Smith to be identified as authors of this work has been asserted in accordance with the Copyright, Designs and Patents Act 1988. 